\title{
Instability of chromosome number and DNA methylation variation induced by hybridization and amphidiploid formation between Raphanus sativus L. and Brassica alboglabra Bailey
}

Xuanli $\mathrm{Li}^{1+}$, Weiwei Guo ${ }^{1+}$, Bing Wang ${ }^{1}$, Xiangsong $\mathrm{Li}^{1}$, Honggao Chen², Lihua Wei ${ }^{1}$, Yanjie Wang ${ }^{1}$, Jiangsheng $\mathrm{Wu}^{2}$, Hong Long ${ }^{1 *}$

\begin{abstract}
Background: Distant hybridization can result genome duplication and allopolyploid formation which may play a significant role in the origin and evolution of many plant species. It is unclear how the two or more divergent genomes coordinate in one nucleus with a single parental cytoplasm within allopolyploids. We used cytological and molecular methods to investigate the genetic and epigenetic instabilities associated with the process of distant hybridization and allopolyploid formation, measuring changes in chromosome number and DNA methylation across multiple generations.

Results: $F_{1}$ plants from intergeneric hybridization between Raphanus sativus $L$. $(2 n=18, R R)$ and Brassica alboglabra Bailey $(2 n=18, C C)$ were obtained by hand crosses and subsequent embryo rescue. Random amplification of polymorphic DNA (RAPD) markers were used to identify the $F_{1}$ hybrid plants. The RAPD data indicated that the hybrids produced specific bands similar to those of parents and new bands that were not present in either parent. Chromosome number variation of somatic cells from allotetraploids in the $F_{4}$ to $F_{10}$ generations showed that intensive genetic changes occurred in the early generations of distant hybridization, leading to the formation of mixopolyploids with different chromosome numbers. DNA methylation variation was revealed using MSAP (methylation-sensitive amplification polymorphism), which showed that cytosine methylation patterns changed markedly in the process of hybridization and amphidiploid formation. Differences in cytosine methylation levels demonstrated an epigenetic instability of the allopolyploid of Raphanobrassica between the genetically stable and unstable generations.

Conclusions: Our results showed that chromosome instability occurred in the early generations of allopolyploidy and then the plants were reverted to largely euploidy in later generations. During this process, DNA methylation changed markedly. These results suggest that, epigenetic mechanisms play an important role in intergeneric distant hybridization, probably by maintaining a genetic balance through the modification of existing genetic materials.
\end{abstract}

\section{Background}

Hybridization between distant genera is a driver of genome evolution and new species formation. Distant hybridization generates novel variation by causing genetic recombination [1]. Allopolyploids resulting from genome

\footnotetext{
* Correspondence: longhong@mail.hzau.edu.cn

+ Contributed equally

${ }^{1}$ College of Life Sciences and Technology, Huazhong Agricultural University, Wuhan, 430070, China

Full list of author information is available at the end of the article
}

doubling during hybridization events are widespread, and include $50 \%-70 \%$ of angiosperms (including crops such as wheat, rapeseed, tobacco and cotton) [2]. Even though allopolyploidy is recognized as important to plant evolution [3], the processes by which it occurs are not fully understood. Coevolution and successful coexistence of genomes from diverse sources within one nuclear and only one parentaly cytoplasm requires coordinated regulation and successful genomic evolution [4-6]. Evidence from rapeseed [7,8], wheat [9-13], and Arabidopsis 
$[14,15]$ demonstrated that allopolyploids can have rapid and extensive genomic variations, phenotypic changes, and genetic instabilities. All these genetic and epigenetic changes were inheritable; however, they did not obey the Mendelian laws of heredity [16].

Mixoploids are chimeras with different ploidies or different numbers of chromosomes existing in the same plant tissue, and include euploidy (chromosome number of offspring is the summation of two parents), hyperploidy (chromosome number of offspring is more than the summation of two parents) and hypoploidy (chromosome number of offspring is less than the summation of two parents) [17]. Hybrids of Brassica orychophragmus exhibit mixoploid traits $[18,19]$.

Epigenetic changes are heritable changes in phenotype or gene expression caused by mechanisms other than changes in the underlying DNA sequence that can be perpetuated for multiple generations [20,21]. Examples of epigenetic changes include gene silencing, DNA methylation, nucleolar dominance, dormant transposon activation, and genome imprinting [22]. DNA methylation changes are detected from many neo-allopolyploids, indicating the possible role of epigenetic mechanisms in DNA methylation. Cytosine methylation changes can be detected using methylation-sensitive amplification polymorphism (MSAP), an AFLP method that uses a pair of isoschizomers, MspI and HpaII [23] that recognize the same restriction site (CCGG) but have different sensitivity to certain methylation states of cytosines. HpaII will not cut if either of the cytosines is fully (double-strand) methylated, whereas, Msp I will not cut if the external cytosine is fully- or hemi-(single-strand) methylated [24]. Thus, for a given DNA sample, the full methylation of the internal cytosine, or hemi-methylation of the external cytosine at the assayed CCGG sites, can be unequivocally distinguished [23,25] using these two restriction enzymes. However, it should be noted that the methylation percentages calculated by MSAP are lower than the total absolute values at the CCGG sites [23,25,26], since HpaII and MspI cannot distinguish several other states of the CCGG sites, including unmethylated CCGG, fully methylated on both sites of cytosine (mCmCGG), or hemi-methylated on the internal site of cytosine (CmCGG). Nevertheless, the MSAP technique is reliable and efficient $[27,28]$.

A distant hybrid amphidiploid, Raphanobrassica $(2 \mathrm{n}=$ $2 \mathrm{x}=36$, RRCC), was synthesized by crossing two diploid species, Raphanus sativus $\mathrm{L} .(2 \mathrm{n}=2 \mathrm{x}=18, \mathrm{RR})$ and Brassica alboglabra Bailey $(2 \mathrm{n}=2 \mathrm{x}=18, \mathrm{CC})$. Meanwhile, characterization of its fertility and crossability with Raphanus sativus and five Brassica species were investigated [29]. In the present paper, we used RAPD analyses to identify the genetic basis of the hybrid recovery by embryo rescue and investigated the genetic instability and epigenetic changes in this allopolyploid. Using the standard cytological chromosome squash method using ovary somatic cells, we surveyed the chromosome numbers from $\mathrm{F}_{4}$ to $\mathrm{F}_{10}$ of the allopolyploid. We also examined changes in DNA methylation of $F_{1}$ hybrids, and the parents as well as $F_{4}$ and $F_{10}$ hybrids on the genome scale using MSAP. We discuss the relevance of these results to the relationship between genetic stability and epigenetic changes.

\section{Results}

$F_{1}$ hybrid obtained through embryo rescue showed intermediate phenotype of the two parents

The cross between $R$. sativus cv. HQ-04 and B. alboglabra was made with HQ-04 as the female parent. Subsequent denudation and embryo rescue, eight $F_{1}$ hybrids were obtained (Figure 1). The leaf morphology of the $F_{1}$ hybrids was obviously different from that of the two parental species, indicating that these $F_{1}$ plants are hybrids. The leaf margin of the $\mathrm{F}_{1}$ hybrid was lobed, with less delamination. However, leaves of female parents (Raphanus) and male parents (Brassica) were divided and indivisus, respectively (Figure 1).

\section{Identification of $F_{1}$ plants with RAPD certified the genetic} basis of the hybrids

Hybrids were identified using eleven 10 bp RAPD primers (sequences provided in Additional file 1) and a total of 58 bands were amplified. Six (10.3\%) of the identified bands were common to both parents and 23 bands $(39.7 \%)$ were only detected in the female parent (Raphanus). Twenty-seven bands (46.6\%) were only detected in the male parent (Brassica). Two bands $(3.44 \%)$ were found specific to the $F_{1}$ hybrid. These results demonstrated that the $F_{1}$ hybrids resulted from a hybridization between $R$. sativus and B. alboglabra. Figure 2 shows two examples of the RAPD amplification results with primers S301 and S2129, respectively.

\section{Chromosome number variation of somatic cells from genetically stable $F_{4}$ to unstable $F_{10}$ revealed the mixopolyploidy characteristic of Raphanobrassica in early generations}

Cytogenic cell spreads were used to compare chromosome numbers in somatic cells from ovaries to investigate the genetic instability of the artificial polyploidy. The chromosome spreading experiments were performed on six tetraploid plants in the $F_{4}$ through $F_{10}$ generations (Table 1). The $\mathrm{F}_{4}$ Raphanobrassica plants were identified as mixopolyploid, with chromosome numbers varying from 27 to 38 (Figure $3 \mathrm{~A}-\mathrm{L}$ ). In all cells investigated, $50.5 \%$ were euploid $(2 \mathrm{n}=36)$.

In the $\mathrm{F}_{5}$ generation, chromosome numbers ranged from 20 to 38 , with most cells having 36 or 38 chromosomes 


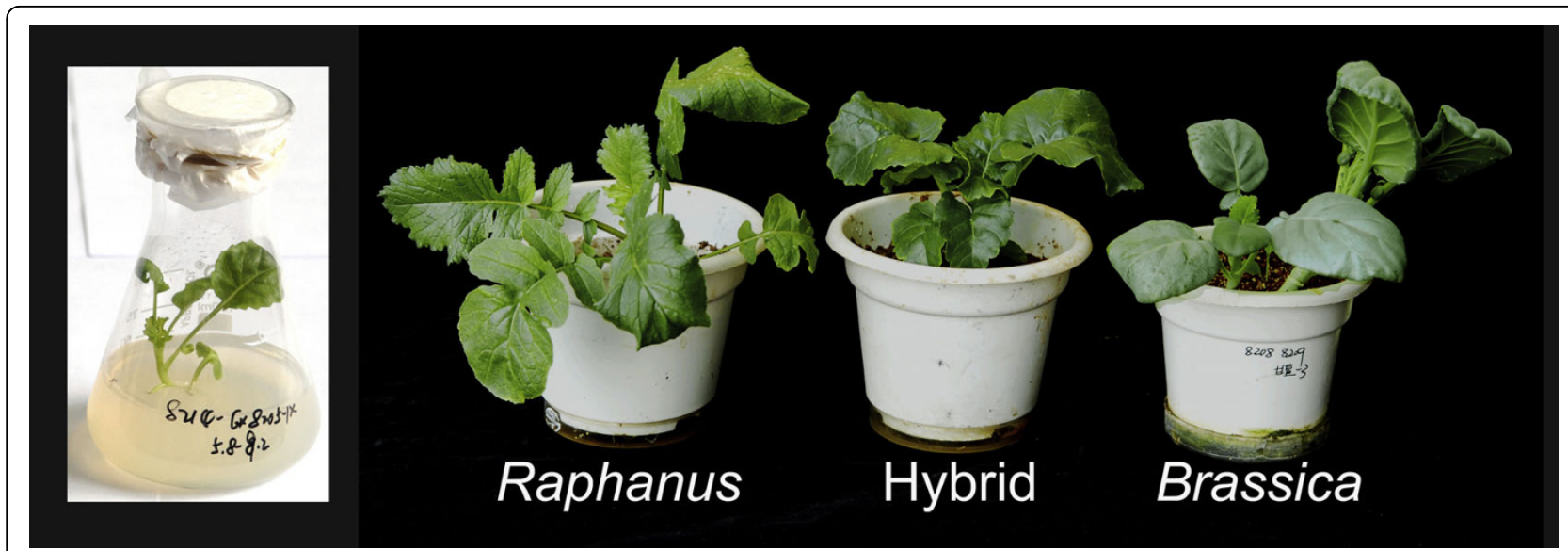

Figure 1 Parents and $F_{1}$ plants after embryo rescue. The Erlenmeyer flask contains an $F_{1}$ seedling $15 d$ after embryo rescue. Plants show the Raphanus and Brassica parents as well as an $\mathrm{F}_{1}$ plant $45 \mathrm{~d}$ after embryo rescue or sowing.

(27.1\% and $20.7 \%$ of total cells respectively), with 37,34 , 35 , and 32 chromosomes being the next most frequent (Table 1). Chromosome numbers in the $\mathrm{F}_{6}$ generation varied from 30 to 38 and the frequency of cells with 38 chromosomes was $5.3 \%$. The somatic chromosome numbers in $\mathrm{F}_{7}$ and $\mathrm{F}_{8}$ varied from 32 to 38 , and $75.5 \%$ and $81.2 \%$ of the cells were euploid $(2 \mathrm{n}=36)$, respectively.

In the $\mathrm{F}_{10}$ generation, $119(97.5 \%)$ cells were euploid with 36 chromosomes (Figure $3 \mathrm{M}$ ); the three exceptional cells had 35 chromosomes.
Extensive alteration in DNA cytosine methylation pattern was associated with formation of intergeneric hybrids In this study, MSAP was used to detect methylation changes in a site-specific manner. Eight EcoRI and eight HpaII/MspI primer pairs were tested (64 in total, see Additional file 2) and twelve primer combinations were selected, based on clear banding patterns and complete reproducibility between two independent DNA extractions from a single donor plant. The 12 pairs of EcoRI + HpaII/MspI selective primer combinations (Additional

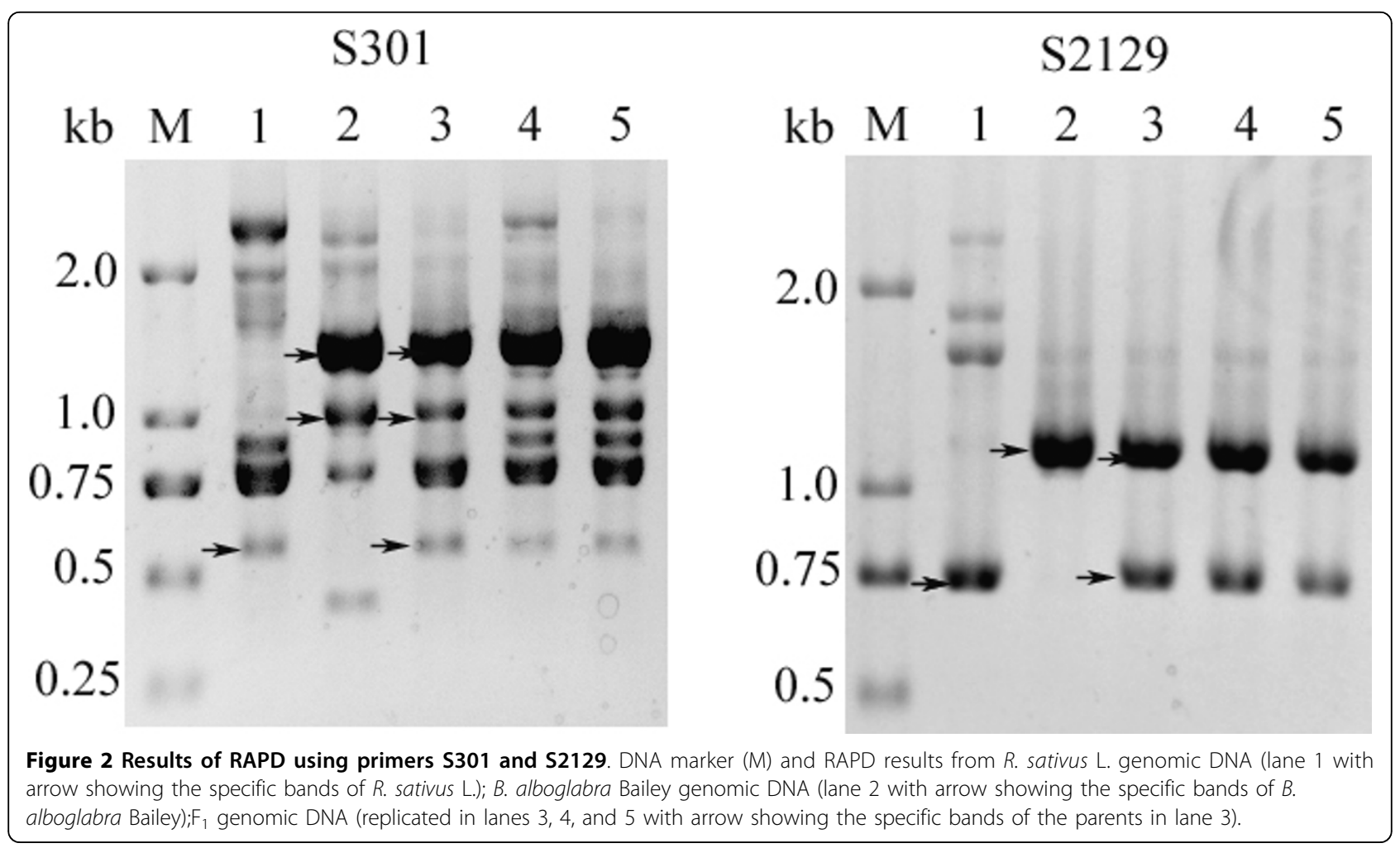


Table 1 Somatic cell types with different chromosome numbers and the percentage in the $F_{4}$ to $F_{10}$ populations

\begin{tabular}{|c|c|c|c|c|c|c|c|c|c|c|c|c|c|c|c|}
\hline \multirow[b]{2}{*}{ Gen. } & \multirow[b]{2}{*}{ Plant No. } & \multicolumn{14}{|c|}{ Somatic cell types } \\
\hline & & $\overline{38^{\text {a) }}}$ & 37 & 36 & 35 & 34 & 33 & 32 & 31 & 30 & 29 & 28 & 27 & $<27$ & total \\
\hline \multirow[t]{2}{*}{$\mathrm{F}_{4}$} & 6 & $26^{\mathrm{b})}$ & 10 & 113 & 19 & 37 & 2 & 8 & 2 & 1 & 1 & 3 & 2 & 0 & 224 \\
\hline & & $11.6^{c)}$ & 4.5 & 50.5 & 8.5 & 16.5 & 0.9 & 3.6 & 0.9 & 0.4 & 0.4 & 1.3 & 0.9 & 0 & 100 \\
\hline \multirow[t]{2}{*}{$\mathrm{F}_{5}$} & 27 & 229 & 151 & 300 & 95 & 128 & 32 & 67 & 7 & 18 & 7 & 20 & 7 & 48 & 1109 \\
\hline & & 20.7 & 13.6 & 27.1 & 8.6 & 11.5 & 2.9 & 6.0 & 0.6 & 1.6 & 0.6 & 1.8 & 0.6 & 4.3 & 100 \\
\hline \multirow[t]{2}{*}{$\mathrm{F}_{6}$} & 27 & 46 & 120 & 365 & 235 & 82 & 9 & 5 & 7 & 3 & 0 & 0 & 0 & 0 & 872 \\
\hline & & 5.3 & 13.8 & 41.9 & 27 & 9.4 & 1.0 & 0.6 & 0.8 & 0.4 & 0 & 0 & 0 & 0 & 100 \\
\hline \multirow[t]{2}{*}{$\mathrm{F}_{7}$} & 32 & 100 & 105 & 1571 & 124 & 102 & 27 & 52 & 0 & 0 & 0 & 0 & 0 & 0 & 2081 \\
\hline & & 4.8 & 5 & 75.5 & 6 & 4.9 & 1.3 & 2.5 & 0 & 0 & 0 & 0 & 0 & 0 & 100 \\
\hline \multirow[t]{2}{*}{$\mathrm{F}_{8}$} & 30 & 67 & 111 & 1846 & 96 & 148 & 0 & 6 & 0 & 0 & 0 & 0 & 0 & 0 & 2274 \\
\hline & & 2.9 & 4.9 & 81.2 & 4.2 & 6.5 & 0 & 0.3 & 0 & 0 & 0 & 0 & 0 & 0 & 100 \\
\hline \multirow[t]{2}{*}{$F_{10}$} & 22 & 0 & 0 & 119 & 3 & 0 & 0 & 0 & 0 & 0 & 0 & 0 & 0 & 0 & 122 \\
\hline & & 0 & 0 & 97.5 & 2.5 & 0 & 0 & 0 & 0 & 0 & 0 & 0 & 0 & 0 & 100 \\
\hline
\end{tabular}

Cytogenetic cell spreading results of somatic cells from ovaries with different chromosome numbers. a) somatic chromosome number; b) cell number; c) frequency (\%).

file 3) amplified by MSAP resulted in 281 clear and reproducible bands for the two parents and $F_{1}$ hybrids (Figure 4a, Table 2).

DNA methylation sites in $F_{1}$ hybrids result in patterns observed to be inherited from one or both parent (s) or induced by intergeneric hybridization, including hyperor hypo-methylation. The MSAP results showed that methylation sites of the parents were transmitted to $F_{1}$ hybrid mainly in a Mendelian way, about $83.27 \%$ (2.49\% from both parents, type A; $80.78 \%$ from only one parent, type B). Meanwhile, $16.72 \%$ were variant bands $(7.47 \%$ were hypermethylation, type $C ; 9.25 \%$ were hypomethylation, type D).

The small number of methylation sites that were similar to both the parents was probably due to the fact that the methylation states in the parents of different genera were not the same. The bands coming from only one parent, i.e. type B, comprised a much larger percentage. Type $C$ (hypermethylation) patterns were slightly less than type $\mathrm{D}$ (hypomethylation), indicating that the level of $F_{1}$ methylation may be lower than that of the parents.

\section{Difference in cytosine methylation levels showed epigenetic instability of allopolyploid of Raphanobrassica between genetically stable and unstable generations}

From the cytogenetic analysis above, we concluded that the genetic instability grew from $F_{4}$ to $F_{10}$, with most somatic cells having 36 chromosomes. The $\mathrm{F}_{4}$ generation was typically unstable while the $F_{10}$ generation was more stable. Since epigenetic mechanisms may play an important role in the correlation of nuclear-cytoplasm system in allopolyploids, we examined DNA methylation changes between $\mathrm{F}_{4}$ and $\mathrm{F}_{10}$.

With 12 pairs of EcoRI+HpaII/MspI selective primer combinations (Additional file 3), 414 and 432 clear and reproducible bands for the two generations were amplified by MSAP (Table 3).

Between the $F_{4}$ and $F_{10}$ generations, the total methylation levels (calculated by adding up the various patterns) increased from $29.17 \%$ to $31.64 \%$. This includes $9.03 \%$ $\left(\mathrm{F}_{4}\right)$ and $11.59 \%\left(\mathrm{~F}_{10}\right)$ hemi-methylation of external $\mathrm{C}$, $20.14 \%\left(\mathrm{~F}_{4}\right)$ and $20.05 \%\left(\mathrm{~F}_{10}\right)$ full-methylation of the internal C (Figure 4b, c, Table 3).

Based on the MSAP patterns, various bands representing non-methylation, hemi-methylation of external $\mathrm{C}$, full methylation of internal $\mathrm{C}$, and full methylation of external $\mathrm{C}$ or both Cs (see Introduction for the rationale of band scoring) were tabulated (Table 4). Fourteen types of amplified bands were obtained after comparing DNA methylation states of $F_{4}$ and $F_{10}$ (Table 4). These bands were divided into two groups: group I showed monomorphic sites, which had no difference in $\mathrm{F}_{4}$ and $F_{10}$, while group II showed polymorphic sites, which had a difference between the two generations. There were two types of bands in group I: IA was full-methylation of the internal C (HpaII do not cut/MspI cut, $\mathrm{H} / \mathrm{M}=$ $-(+)$, and IB was hemi-methylation of the external C (HpaII cut/MspI do not cut, $\mathrm{H} / \mathrm{M}=+/-$ ). The total number of these bands was 102 (Table 4), indicating that $58.29 \%(102 / 175)$ of DNA sequences had no changes in methylation between the $\mathrm{F}_{4}$ and $\mathrm{F}_{10}$ generations. These results indicated that most methylation types could be stably transmitted from one generation to the next. Group II was divided into 12 types, suggesting that there were some DNA methylation changes between the two generations (Table 4). Some bands were only detected in $F_{4}$, while others were only detected in $\mathrm{F}_{10}$ (Figure $4 \mathrm{~b}, \mathrm{c}$ ). A total of 71 bands like these could be divided into 5 sections (Table 4, IIA, IIB, IIC, IID, IIE). Among these, IIA and IIB were the most 


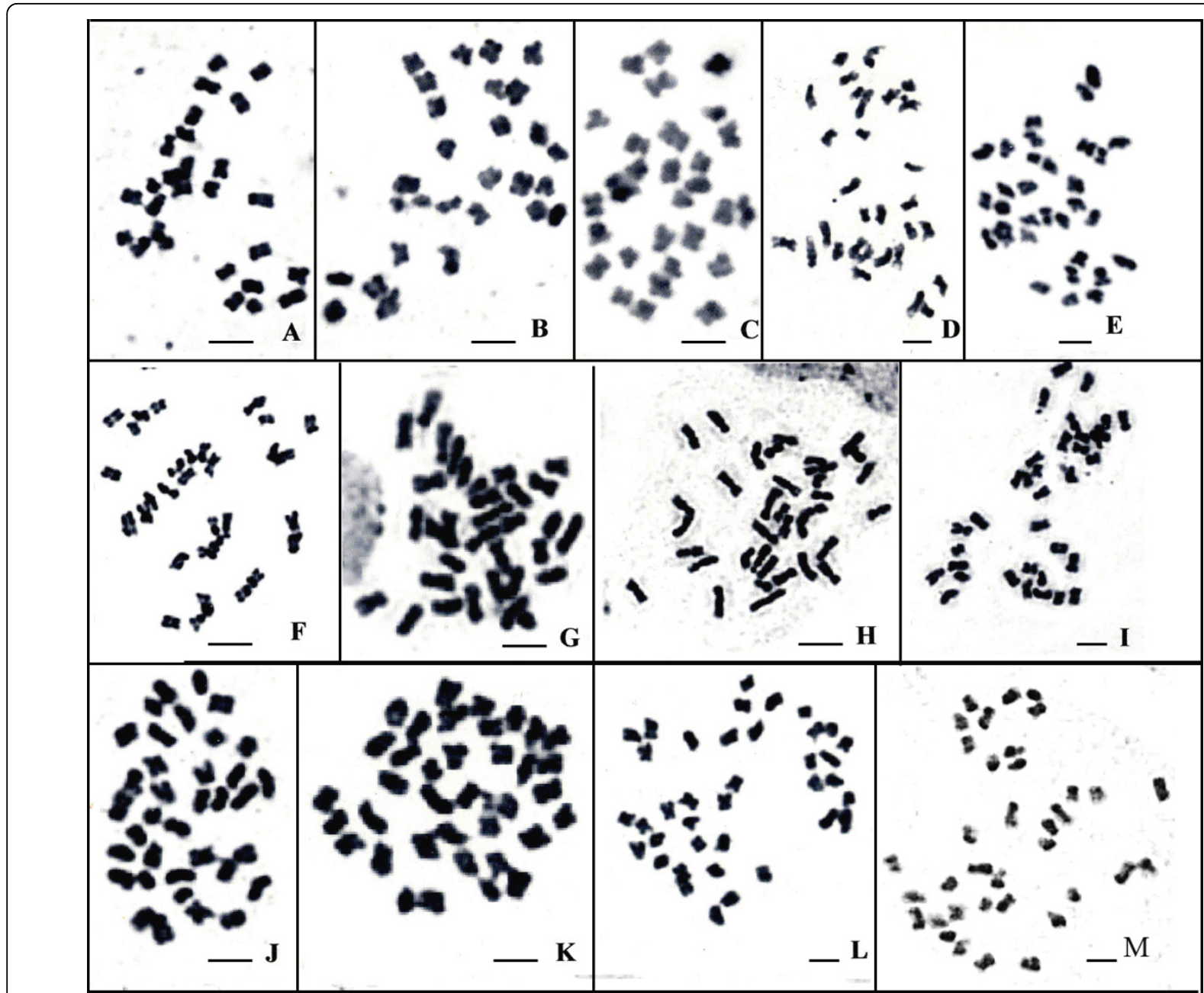

Figure 3 Chromosome numbers of $F_{4}$ and $F_{10}$ showing their mixopolyploid and euploid character, respectively. Chromosome numbers of $F_{4}\left(A-L, 2 n=27-38\right.$, respectively) and $F_{10}(M, 2 n=36)$. Bar $=5 \mu \mathrm{m}$.

abundant, with 27 and 18 bands, respectively. Section IIA showed no bands in both or one of HpaII/MspI digested lanes in $\mathrm{F}_{4}$, while it had bands in $\mathrm{F}_{10}$. These patterns (IIA- $1,-+++$, IIA-2, - + + + IIA-3, + - + +) indicated full hypomethylation in $\mathrm{F}_{10}$, present for $15.43 \%$ of the total. In contrast, Section IIB had bands in both or one of the HpaII/MspI digested lanes in the $\mathrm{F}_{4}$, and no bands were produced in $\mathrm{F}_{10}$. These patterns (IIB-1, + + - , IIB-2, + - - , IIB-3, - + - -) indicated a full methylation of external $C$ or both $C s$ in the $F_{10}$, present in $10.29 \%$ of the total. Sections C, D, and E showed hypo- and hypermethylation states in $\mathrm{F}_{10}$ compared to the $\mathrm{F}_{4}$, that had $6.29 \%, 5.71 \%$, and $4.00 \%$, respectively.

\section{Discussion}

Distant hybridization occurs under both natural and artificial conditions. After genome duplication, allopolyploids can be obtained, and these polyploids play a significant role in the origin and evolution of many plant species. In crop improvement, allopolyploids are also valuable as bridge materials for breeding. During the course of hybridization, it is difficult to get $F_{1}$ plants due to sterility. The $F_{1}$ hybrid could be the real hybrid containing whole or partial genetic material from both of the parents; the false hybrid resulting from female parthenogenesis or self-crossing; or an introgression where most of the male parent DNA was digested by the female nuclease and a few segments combined with the genome of the female parent.

Allopolyploidy has been intensively studied in naturally evolved allopolyploids of wheat, cotton, rapeseed, Arabidopsis, and tomato. Genetic changes are best evaluated by comparing the parental lines and their progeny; however, it is difficult to ascertain the parents in naturally evolved allopolyploids since genetic changes have occurred in subsequent generations. 


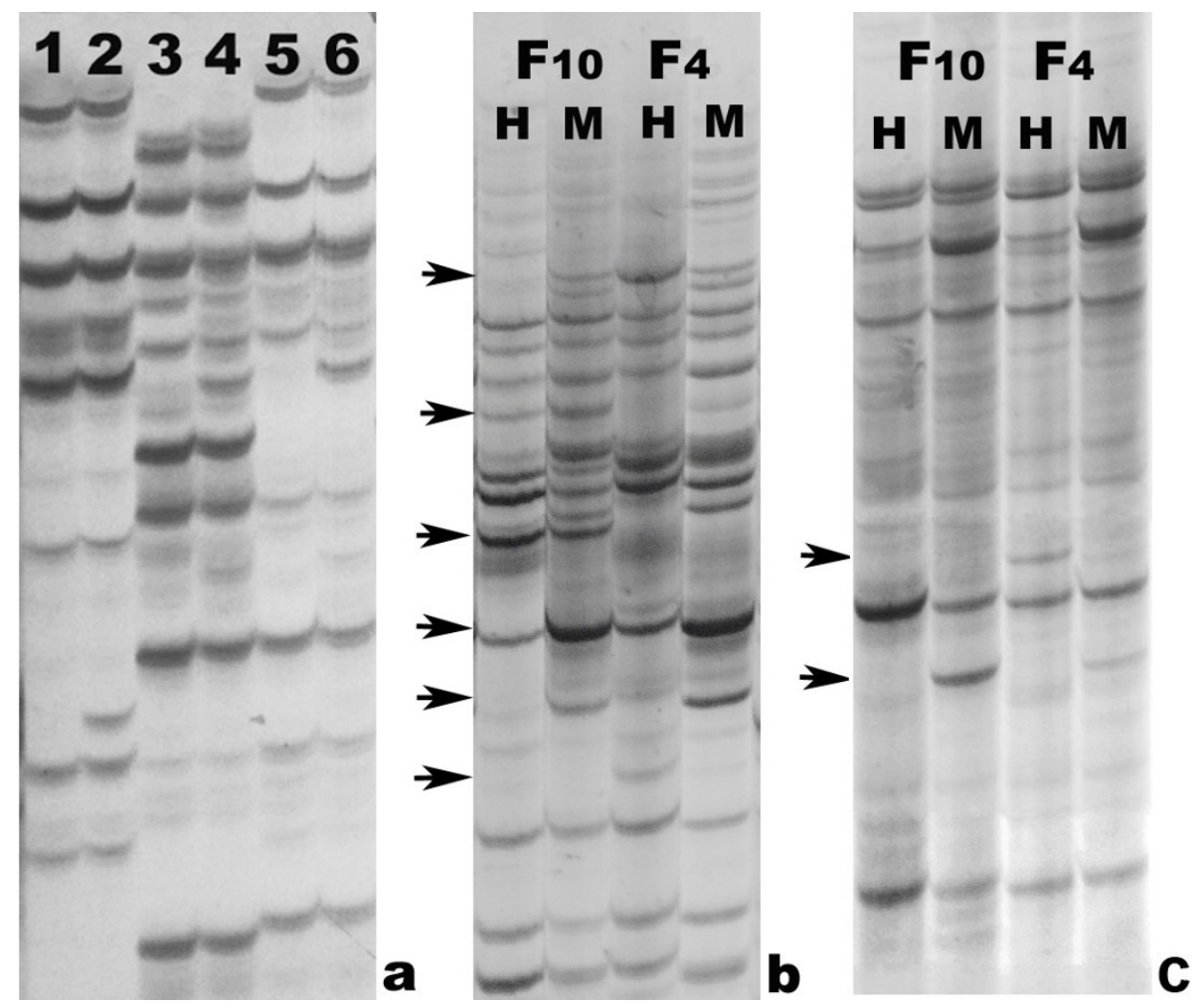

Figure 4 Examples of MSAP profiles showing various types of locus-specific DNA methylation inheritance and variation in $F_{1}$ hybrid and their parents (a) and different types of locus-specific DNA methylation inheritance and variation in $F_{4}$ and $F_{10}$, and the $F_{4}$ and $F_{10}$ DNA methylation patterns (b,c). (a). Primer combination is EcoRl+ ATT/Hpall (Mspl) + ACC. Amplification results of Hpall-digested genomic DNA of $R$. sativus L. (Lane 1), B. alboglabra Bailey (Lane 3) and $F_{1}$ hybrids (Lane 5) Amplification results of Mspl-digested genomic DNA of $R$. sativus L. (Lane 2), B. alboglabra Bailey (Lane 4), and $F_{1}$ hybrids (Lane 6). (b) and (c). Primer combinations are EcoRl + AGG/Hpall (Mspl) + GAT and EcoRl $+\mathrm{AGG} / \mathrm{Hpall}(\mathrm{Mspl})+\mathrm{TCG}$, respectively. Arrows show variations of the various methylation patterns. H: Hpall, M: Mspl.

Artificial allopolyploids have defined parents and genetic lineages, making them suitable for elucidating changes that occur during the formation of allopolyploids.

The hybridization between Raphanus and Brassica was first reported by Sageret in 1862 [30]. About 100 years later, Karpechenko identified an $\mathrm{F}_{1}$ hybrid between Raphanus and Brassica [31,32]. To transfer the nucleic genes of Brassica tournefortii (TT) into B. carinata (BBCC), Mukhopadhyay et al. produced a bridge species (TCBB) by protoplast fusion between the $\mathrm{F}_{1}$ hybrid (TC) of $B$. tournefortii $\times$ B. oleracea and B. nigra (BB) and RAPD primers were used to show that all the hybrids had specific bands from the genomes of the parents. These results indicated that the $\mathrm{T}, \mathrm{B}$, and $\mathrm{C}$ genomes may coexist in a hybrid state. RFLP molecular markers confirmed that these hybrids contained chloroplast and mitochondrion genomes of Brassica tournefortii and B. nigra [33]. Chrungu et al. (1999) synthesized allotetraploids of $B$. maurorum-B. napus, $B$. maurorum- $B$. carinata, and $B$. maurorum- $B$. nigra through interspecific hybridization and genomic doubling and proved the reality of the hybrids through RAPD and RFLP [34]. In the present study, we synthesized $F_{1}$ hybrids through sexual hybridization followed by embryo rescue and identified its origin with RAPD. The results showed that $F_{1}$ hybrids lost some of the specific or common bands of the parents. The probable reason was that hybridization resulted in a genomic recombination and changed the primer binding sites of some segments, leading to the appearance or disappearance of some DNA bands.

Our results showed that, DNA methylation patterns differed substantially between the parents and $F_{1}$ hybrids, indicating its possible key role in transgenerational stability. During the process of hybrid formation, DNA methylation patterns may adjust to some extent to coordinate the interactions among nuclear genes or those between nuclear genes and cytoplasmic genes. Both hypomethylation and hypermethylation events may affect gene expression patterns. In our work, hypomethylation was a more frequent than hypermethylation.

Polyploidy has played a fundamental role in the evolution of higher plants. Plant breeders have been routinely producing allopolyploids with interesting agronomic 
Table 2 Methylation pattern in $\mathbf{F}_{\mathbf{1}}$ hybrid and parents

\begin{tabular}{|c|c|c|c|c|c|c|c|c|}
\hline \multirow[t]{2}{*}{ type } & \multicolumn{2}{|c|}{ male } & \multicolumn{2}{|c|}{ female } & \multicolumn{2}{|c|}{$F_{1}$} & \multirow[t]{2}{*}{ band } & \multirow[t]{2}{*}{ percentage } \\
\hline & Hpall & Mspl & Hpall & Mspl & Hpall & Mspl & & \\
\hline \multirow[t]{2}{*}{ A } & 0 & 1 & 0 & 1 & 0 & 1 & 5 & \\
\hline & 1 & 0 & 1 & 0 & 1 & 0 & 2 & $2.49 \%$ \\
\hline \multirow[t]{15}{*}{ B } & 1 & 1 & 0 & 1 & 0 & 1 & 17 & \\
\hline & 0 & 1 & 1 & 1 & 0 & 1 & 2 & \\
\hline & 1 & 1 & 0 & 0 & 0 & 0 & 27 & \\
\hline & 0 & 0 & 1 & 0 & 0 & 0 & 4 & \\
\hline & 0 & 0 & 0 & 1 & 0 & 0 & 3 & \\
\hline & 0 & 0 & 1 & 0 & 1 & 0 & 4 & \\
\hline & 0 & 0 & 1 & 1 & 0 & 0 & 25 & \\
\hline & 1 & 1 & 0 & 0 & 1 & 1 & 54 & \\
\hline & 1 & 1 & 0 & 1 & 1 & 1 & 9 & \\
\hline & 0 & 0 & 0 & 1 & 0 & 1 & 10 & \\
\hline & 0 & 0 & 1 & 1 & 1 & 1 & 62 & \\
\hline & 1 & 0 & 1 & 0 & 0 & 0 & 1 & \\
\hline & 0 & 1 & 1 & 0 & 1 & 0 & 2 & \\
\hline & 0 & 1 & 0 & 0 & 0 & 1 & 6 & \\
\hline & 1 & 1 & 1 & 0 & 1 & 0 & 1 & $80.78 \%$ \\
\hline \multirow[t]{8}{*}{ C } & 1 & 0 & 1 & 0 & 0 & 0 & 1 & \\
\hline & 0 & 1 & 0 & 1 & 0 & 0 & 1 & \\
\hline & 1 & 1 & 1 & 1 & 0 & 0 & 7 & \\
\hline & 1 & 1 & 1 & 1 & 0 & 1 & 4 & \\
\hline & 1 & 1 & 1 & 1 & 1 & 0 & 1 & \\
\hline & 1 & 1 & 0 & 1 & 0 & 0 & 4 & \\
\hline & 1 & 0 & 1 & 1 & 0 & 0 & 1 & \\
\hline & 0 & 1 & 1 & 1 & 0 & 0 & 2 & $7.47 \%$ \\
\hline \multirow[t]{7}{*}{ D } & 0 & 0 & 0 & 0 & 1 & 0 & 1 & \\
\hline & 0 & 0 & 0 & 0 & 0 & 1 & 3 & \\
\hline & 0 & 0 & 0 & 0 & 1 & 1 & 5 & \\
\hline & 0 & 1 & 0 & 1 & 1 & 1 & 8 & \\
\hline & 0 & 1 & 0 & 0 & 1 & 1 & 5 & \\
\hline & 0 & 0 & 1 & 0 & 1 & 1 & 3 & \\
\hline & 0 & 0 & 0 & 1 & 1 & 1 & 1 & $9.25 \%$ \\
\hline total & & & & & & & 281 & \\
\hline
\end{tabular}

DNA methylation patterns in $\mathrm{F}_{1}$ hybrid and parents. "0" stands for the absence of a band, and " 1 " stands for the presence of a band.

traits to be used for breeding programs. However, the poor genetic stability of allopolyploids in early generations is a challenge for plant breeding programs.
Table 4 Different patterns of methylation in $F_{\mathbf{4}}$ and $F_{\mathbf{1 0}}$

\begin{tabular}{|c|c|c|c|c|c|c|c|}
\hline \multicolumn{2}{|c|}{ Patterns } & \multicolumn{2}{|c|}{$\mathrm{F}_{4}$} & \multicolumn{2}{|c|}{$\mathrm{F}_{10}$} & \multirow{2}{*}{$\begin{array}{l}\text { Number of } \\
\text { sites }\end{array}$} & \multirow{2}{*}{$\begin{array}{l}\text { Ratio of different patterns } \\
(\%)\end{array}$} \\
\hline & & $\mathrm{H}$ & $\mathbf{M}$ & $\mathrm{H}$ & $M$ & & \\
\hline I & $\mathrm{IA}$ & - & + & - & + & 74 & 58.29 \\
\hline & $\mathrm{IB}$ & + & - & + & - & 28 & \\
\hline \multirow[t]{3}{*}{$\| A$} & $\| \mathrm{A} 1$ & - & - & + & + & 10 & 15.43 \\
\hline & $\| \mathrm{A} 2$ & - & + & + & + & 6 & \\
\hline & $\| \mathrm{A} 3$ & + & - & + & + & 11 & \\
\hline \multirow[t]{3}{*}{ B } & $\| \mathrm{B} 1$ & + & + & - & - & 3 & 10.29 \\
\hline & IIB2 & + & - & - & - & 7 & \\
\hline & IIB3 & - & + & - & - & 8 & \\
\hline \multirow[t]{2}{*}{ C } & $\| \mathrm{C} 1$ & - & - & - & + & 3 & 6.29 \\
\hline & $\| \mathrm{C} 2$ & - & - & + & - & 8 & \\
\hline \multirow[t]{2}{*}{ D } & IID1 & + & + & - & + & 8 & 5.71 \\
\hline & IID2 & + & + & + & - & 2 & \\
\hline \multirow[t]{2}{*}{$E$} & IIE1 & + & - & - & + & 2 & 4.00 \\
\hline & IIE2 & - & + & + & - & 5 & \\
\hline
\end{tabular}

DNA methylation number of sites and ratio of different patterns. "- " stands for the absence of a band, and " + " stands for the presence of a band. $\mathrm{H}$ and $\mathrm{M}$ are the combinations of enzymes of EcoRI/Hpall and EcoRI/Mspl, respectively.

Intergeneric hybridization between a long genetic distance may cause mixoploidy, leading to genetic instability. Hybrids between Orychophragmus violaceus $(2 \mathrm{n}=$ $24)$ and cultivated Brassica species, including tetraploids (B. carinata and $B$. juncea) and diploids (B. campestris and $B$. nigra), led to mixoploids $[18,19]$. For example, the hybrid with $B$. campestris $(2 \mathrm{n}=20$, AA) was mixoploid $(2 \mathrm{n}=23-42)$, and cells with $2 \mathrm{n}=34$ were most frequent. Partial separation of parental genomes during mitosis, leading to the addition of O. violaceus chromosomes to the B. campestris complement, was proposed to explain the findings in the mitotic and meiotic cells of the hybrid and its progeny. In crosses with $B$. nigra $(2 \mathrm{n}=16, \mathrm{BB})$, a small fraction consisted of mixoploids $(2 \mathrm{n}=16-18)$, predominantly with $2 \mathrm{n}=16$ cells, and three plants, each with a specific morphology, were mixoploids consisting of cells with varying ranges of chromosome numbers $(2 \mathrm{n}=17-26,11-17$ and 14-17). The origin of these different types of plants was inferred to be the result of complete and partial separation of

Table 3 Levels of cytosine methylation at the CCGG sites of $F_{4}$ and $F_{10}$ of allopolyploid of Raphanobrassica

\begin{tabular}{|c|c|c|c|c|c|}
\hline \multirow[b]{2}{*}{ Generations } & \multirow[b]{2}{*}{$\begin{array}{l}\text { Total } \\
\text { sites }\end{array}$} & \multirow[b]{2}{*}{$\begin{array}{l}\text { Non-methylated sites (number and } \\
\text { frequency) }\end{array}$} & \multicolumn{3}{|c|}{ Methylated sites (number and frequency) } \\
\hline & & & total & $\begin{array}{l}\text { hemi-methylation of the } \\
\text { external Cs }\end{array}$ & $\begin{array}{l}\text { full-methylation of the } \\
\text { external Cs }\end{array}$ \\
\hline $\mathrm{F}_{4}$ & 432 & $306(70.83 \%)$ & $\begin{array}{c}126 \\
(29.17 \%)\end{array}$ & $87(20.14 \%)$ & $39(9.03 \%)$ \\
\hline$F_{10}$ & 414 & $283(68.36 \%)$ & $\begin{array}{c}131 \\
(31.64 \%)\end{array}$ & $83(20.05 \%)$ & $48(11.59 \%)$ \\
\hline
\end{tabular}

Methylated and non-methylated sites (number and frequency in the $F_{4}$ and $F_{10}$ generations) were calculated according to the clear and reproducible bands of MSAP. 
parental genomes and the loss of $O$. violaceus chromosomes.

In the present study, our intergeneric hybrid of $R$. sativus $\mathrm{L}$. and $B$. alboglabra Bailey was a mixoploid $(2 \mathrm{n}=23-42)$ in the early generations $\left(\mathrm{F}_{4}-\mathrm{F}_{8}\right)$. After several generations, mixoploids gradually turned to euploids through formation of neo-chromosomes or chromosome elimination. The possible cytological mechanisms pertaining to these hybrid generations and the genetic motifs from unstable to stable generations are unknown

We suggest that the stability of the $F_{10}$ generation is a result of epigenesist. Epigenetic changes were mainly materialized by covalent modifications of DNA methylation and protein modifications (methylation, acetylation, phosphorylation). In plants, newly acquired epigenetic states of transcriptional gene activity can be readily transmitted to the progeny through meiosis. Epigenetic reconfiguration after hybridization between diploid members of the same species may be an important mechanism for reconciling two non-identical genomes in the same nucleus as allopolyploid formation occurs $[5,35,36]$.

Our results show that methylation patterns and methylation states changed in the intergeneric hybrid both in the process of $F_{1}$ hybrid formation and through the formation of generations of genetically unstable and stable progenies. DNA methylation levels of $F_{4}$ and $F_{10}$ (29.17\% and $31.64 \%)$ did not show a great difference, indicating the similar status of DNA methylation between stable and unstable generations. These levels were similar to that of Arabidopsis seedlings (35\%-43\%) [37], but these were much higher than that of rice leaves (16.30\%) [38]. These differences in DNA methylation among different species may be caused by detection methods (primer numbers, amplification conditions, time of electrophoresis, and staining methods), material differences (seed, seedling, mature leaves), or genetic control. For DNA methylation patterns, hemi-methylation levels of the external cytosine at CCGG sites of $F_{4}$ and $F_{10}$ are $20.14 \%$ and $20.05 \%$, respectively, while full methylation of the internal cytosine at CCGG sites of $\mathrm{F}_{4}$ and $F_{10}$ were $9.03 \%$ and $11.59 \%$, respectively. These results showed that hemi-methylation was the main DNA methylation pattern in both $F_{4}$ and $F_{10}$ generations. The full-methylation level of the $F_{10}$ was higher than that of the $\mathrm{F}_{4}$, indicating that methylation changes from an unstable to a stable generation happened mainly on full-methylation sites. The relationship between the changes in genetics and epigenetics remains elusive. We suggest that the inheritance of allopolyploids seems to be governed by multiple mechanisms, including both genetic and epigenetic mechanisms. The contribution of these different mechanisms to inheritance is largely unknown, as many of these interact with each other.

\section{Conclusions}

Wide hybridization followed by genome doubling is a prominent model of speciation in higher plants. Nevertheless, little is known regarding the early events of coordination required to ensure compatibility for the coexistence of two or more divergent genomes derived from different species in a single nucleus with one parental cytoplasm. Here we presented evidence of genetic and epigenetic variation resulting from hybrid formation. Although a deeper insight into these changes is still needed, epigenetic, especially DNA methylation patterns and levels, is undoubtedly one of the important factors in controlling allopolyploid formation and development. One can expect that the multiple, comparative analyses of biological events during the formation of hybrids will ultimately facilitate an inference of the rules and principles that control the fate of duplicated genes and will lead to an enhanced appreciation of the effects of distant hybridization on the formation and the natural evolution of new species.

\section{Methods}

\section{Plant materials}

Selfed generations of Raphanus sativus cv. HQ-04 (a vegetable radish landrace in Wuhan) and Brassica alboglabra were used to synthesize amphidiploid Raphanobrassica. The seeds were preserved at the National Rapeseed Engineering Center, Huazhong Agricultural University, Wuhan, China.

\section{Field hybridization}

Planting was carried out in the field of the National Rapeseed Engineering Center, Huazhong Agricultural University, Wuhan, China. The cross between $R$. sativus cv. HQ-04 and B. alboglabra was made with HQ-04 as the female parent. For production of $F_{1}$ hybrid, the female parents were denudated buds, castrated, and bagged. Male parents were also bagged $1 \mathrm{~d}$ before flowering. After flowering, pollinations were performed, followed by bagging and labelling with tags to record date and hybrid combination.

After embryo rescue (see below), $\mathrm{F}_{1}$ plants were treated with $0.3 \%$ aqueous colchicine to double the chromosome number. After two generations of self-pollination, six partially fertile putative amphidiploid plants $(2 \mathrm{n}=$ 36) with intermediate morphological characters were selected from $41 \mathrm{~F}_{4}$ plants. Seeds harvested from these plants after self-pollination were planted and $385 \mathrm{~F}_{5}$ plants were generated. They were permitted to pollinate 
each other within a mosquito nylon net. Six $\mathrm{F}_{5}$ plants with higher fertility were selected. Using similar procedures, selections were done until the $\mathrm{F}_{10}$ generation.

\section{Embryo rescue}

At 5, 9, and $13 \mathrm{~d}$ after fertilization, ovaries were cut, surface-sterilized with $75 \%$ alcohol for $0.5 \mathrm{~min}$, immersed in $0.1 \%$ mercuric chloride for $12 \mathrm{~min}$, and washed with distilled water three times. Inoculation was done using the medium MS $+0.2 \mathrm{mg} / \mathrm{L} 6-\mathrm{BA}, 25-27^{\circ} \mathrm{C}$, and daylight of $16 \mathrm{~h}$ with $8001 \mathrm{ux}$. After $20 \mathrm{~d}$, young embryos were separated and transferred to MS medium until the seedlings grew.

\section{Genomic DNA isolation and RAPD}

Seeds of $R$. sativus, B. alboglabra, $\mathrm{F}_{4}$ and $\mathrm{F}_{10}$ were planted in a Sanyo growth cabinet (Osaka, Japan) after surface sterilization with $75 \%$ alcohol as described above. Genomic DNA was isolated from expanded leaves in parental, $F_{1}$, and subsequent generations of plants using a modified CTAB method [39] and a phenol purification. Quality and quantity of DNA were inspected by both gel electrophoresis and spectrometric assays. One hundred random primers with $10 \mathrm{bp}$ were selected for PCR amplification of genomic DNA from the parents and $F_{1}$ hybrid. The thermal cycles started with $94^{\circ} \mathrm{C}$ for $5 \mathrm{~min}$; then 40 cycles of $94^{\circ} \mathrm{C}$ for $1 \mathrm{~min}$, $37^{\circ} \mathrm{C}$ for $1 \mathrm{~min}, 72^{\circ} \mathrm{C}$ for $1 \mathrm{~min}$, ending with $72^{\circ} \mathrm{C}$ for 7 min. The amplification products were separated on $1.5 \%$ agarose gel with $0.5 \mu \mathrm{g} / \mathrm{ml}$ ethidium bromide in $0.5 \times \mathrm{TBE}$ buffer at $100 \mathrm{~V}$ for $3.5-4 \mathrm{~h}$ and photographed under ultraviolet light.

\section{Cytological analysis}

Ovaries collected from each plant were used for cytological study following the procedure of Li et al. [18] with modifications. Briefly, materials were dissected under a stereomicroscope and treated with $0.002 \mathrm{~mol} / \mathrm{L}$ 8-hydroxyquinoline for $3 \mathrm{~h}$ in total darkness at room temperature, followed by fixation Carnoy's fixation solution (ethanol: acetic acid $=3: 1, \mathrm{v} / \mathrm{v}$ ) for at least $1 \mathrm{~h}$ at room temperature. The materials were macerated in $1 \mathrm{~mol} / \mathrm{L}$ hydrochloric acid at $60^{\circ} \mathrm{C}$ for $10 \mathrm{~min}$. After washing three-five times to eliminate residual hydrochloric acid and staining with carbol fuschin for $1 \mathrm{~min}$, the materials were squashed for observation in $45 \%$ acetic acid. More than 30 chromosome micrographs were observed under an Olympus BX61 microscope and recorded with spot pursuit slider digital camera (USA). A total of 224 somatic cells were observed from from ovaries of six plants in $\mathrm{F}_{4}$ generation and chromosomes of 1,109 somatic cells from ovaries of 27 plants in the $F_{5}$ were investigated. Chromosomes of 872 somatic cells from ovaries of 27 plants in $F_{6}$ and 122 cells from ovaries in 22 plants of the $F_{10}$ were observed.

\section{MSAP analysis}

MSAP, a technique based on AFLP, was used to detect methylation changes on specific sites [22].

A pair of isoschizomers, HpaII/MspI, was used instead of MseI in AFLP. HpaIland MspI form a pair of isoschizomers that recognize the same restriction site (5'CCGG) but have different sensitivity to methylation of the cytosines.

The MSAP protocol used in this study was essentially as reported previously [23]. The restriction enzymes EcoRI, HpaII, and MspI were purchased from the New England Biolabs Inc. (Beverly, Mass.). In brief, one pair of pre-selective primers and 16 pairs of selective primers were used for amplifications. A silver-stained sequencing gel was used to resolve and visualize the amplification products. Only clear and completely reproducible bands that appeared in two independent PCR amplifications (starting from the digestion-ligation step, i.e., the first step of MSAP) were scored. The scored MSAP bands represent three major cytosine methylation states: (1) hemi-methylation of the external $\mathrm{C}$, which are bands present in HpaII but absent from the corresponding MspI-digest, i.e., pattern $\mathrm{H} / \mathrm{M}=+/-$; (2) full methylation of the internal $\mathrm{C}$, which are bands absent from HpaII but present in the corresponding $M s p I$-digest, i.e., pattern $\mathrm{H} / \mathrm{M}=-/+$, and; (3) full methylation of the external $\mathrm{C}$ or both Cs, which are bands absent from both HpaIIand $M s p$ I-digest but present in the alternative tissue of the same genotype, i.e., pattern $\mathrm{H} / \mathrm{M}=-/-$ in tissue 1 versus $H / M=+/+$ in tissue2, and vice versa.

\section{Acknowledgements}

We thank Prof. Xuemin Wang (Donald Danforth Plant Science Center, Missouri-Saint Louis, USA) for his critical reading of the manuscript and Dr. David McGraw (Department of Biology, University of Missouri-Saint Louis, USA) for checking the language. We acknowledged Prof. Gayle Volk (USDA ARS-NCGRP) for his carefully improvement of the expression and English language. This study was supported by the National Foundation for Fostering Talents of Basic Sciences (J0730649, China) and the Returned Overseas Chinese Scholars, State Education Ministry (4002-082017).

\section{Author details}

College of Life Sciences and Technology, Huazhong Agricultural University, Wuhan, 430070, China. ${ }^{2}$ National Key Laboratory of Crop Genetic Improvement, Huazhong Agricultural University, Wuhan, 430070, China.

\section{Authors' contributions}

XuL, XiL, LW, YW, and BW carried out the molecular genetic studies. BW and WG participated in the sequence alignment and drafted the manuscript. HC, BW, and HL carried out the cytological analysis. LW and JW participated in the design of the study. HL designed and finalized the manuscript. All authors read and approved the final manuscript.

Received: 14 December 2009 Accepted: 17 September 2010 Published: 17 September 2010 


\section{References}

1. Gregory TR: The evolution of the genome Elsevier Inc 2007.

2. Masterson J: Stomatal size in fossil plants: evidence for polyploidy in majority of angiosperms. Science 1994, 264:421-424.

3. Wendel JF: Genome evolution in polyploids. Plant Molecular Biology 2000 42:156-159.

4. Eckardt NA: A sense of self: the role of sequence elimination in allopolyploidization. The Plant Cell 2001, 13:1699-1704.

5. Pikaard CS: Genomic change and gene silencing in polyploids. Trend Genet 2001, 17:675-677.

6. Risenberg L: Polyploid evolution: keeping the peace at genomic reunions. Current Biology 2002, 11:925-929.

7. Song KM, Lu P, Tang K, Osborn TC: Rapid genome change in synthetic polyploids of Brassica and its implications for polyploid evolution. Proc Natl Acad Sci USA 1987, 92:7719-7723.

8. Schranz ME, Osborn TC: Novel flowering time variation in the resynthesized polyploids Brassica napus. J Hered 2000, 91:242-246.

9. Feldman M, Liu B, Sega G, Abbo S, Vega JM: Rapid elimination of lowcopy DNA sequences in polyploid wheat: a possible mechanism for differentiation of homoeologous chromosomes. Genetics 1997, 147:1381-1387.

10. Liu B, Vega JM, Segal G, Abbo S, Rodova M, Feldman M: Rapid genomic changes in newly synthesized amphiploids of Triticum and Aegilops. I. changes in low-copy noncoding DNA sequences. Genome 1998, 41:272-277.

11. Liu B, Vega JM, Feldman M: Rapid genomic changes in newly synthesized amphiploids of Triticum and Aegilops II changes in low-copy coding DNA sequences. Genome 1998, 41:535-542.

12. Ozkan H, Levy AA, Feldman M: Allopolyploidy-induced rapid genome evolution in the wheat (Aegilops-Triticum) group. The Plant Cell 2001, 13:1735-1747

13. Shaked H, Kashkush K, Ozkan H, Feldman M, Levy AA: Sequence elimination and cytosine methylation are rapid and reproducible responses of the wheat genome. The Plant Cell 2001, 13:1749-1759.

14. Comai L, Tyagi AP, Winter K, Holmes-Davis R, Reynolds SH, Stevens Y, Byers $B$ : Phenotypic instability and rapid gene silencing in newly formed Arabidopsis allotetraploids. The Plant Cell 2000, 12:1551-1567.

15. Lee HS, Chen ZJ: Protein-coding genes are epigenetically regulated in Arabidopsis polyploids. Proc Natl Acad Sci USA 2001, 98:6753-6758.

16. Liu B, Wendel JF: Non-Mendelian phenomena in polyploid genome evolution. Current Genomics 2002, 3:489-506.

17. Alana AR, Lima W, Mutschlera MA, Earle ED: Complementary strategies for ploidy manipulations in gynogenic onion (Allium cepa L.). Plant Science 2007, 173:25-31.

18. Li Z, Liu HL, Luo P: Production and cytogenetics of intergeneric hybrids between Brassica napus and Orychophragmus violaceus. Theor Appl Genet 1995, 91:131-136.

19. Li Z, Liu Y: Cytogenetics of intergeneric hybrids between Brassica species and Orychophragmus violaceus. Progress in natural science 2001, 11:721-727.

20. Vrana PB, Fossella JA, Matteson P, del Rio T, O'Neill MJ, Tilghman SM: Genetic and epigenetic incompatibilities underlie hybrid dysgenesis in Peromyscus. Nat Genet 2000, 25:120-24

21. Bowers JE, Chapman BA, Rong J, Paterson AH: Unravelling angiosperm genome evolution by phylogenetic analysis of chromosomal duplication events. Nature 2003, 422:433-438

22. Chen ZJ: Genetic and epigenetic mechanisms for gene expression and phenotypic variation in plant polyploids. Annu Rev Plant Biol 2007, 58:377-406.

23. Reyna-Lopez GE, Simpson J, Ruiz-Herrera J: Differences in DNA methylation patterns are detectable during the dimorphic transition of fungi by amplification of restriction polymorphisms. Mol Gen Genet 1997, 253:703-710.

24. McClelland M, Nelson M, Raschke E: Effect of site-specific modification on restriction endonucleases and DNA modification methyltransferases. Nucleic Acids Res 1994, 22:3640-3659.

25. Cervera MT, Ruiz-García L, Martinez-Zapater JM: Analysis of DNA methylation in Arabidopsis thaliana based on methylation-sensitive AFLP markers. Mol Genet Genomics 2002, 268:543-552.

26. Dong $Z Y$, Wang $Y M$, Zhang ZJ, Shen $Y$, Lin XY, Ou XF, Han FP, Liu B: Extent and pattern of DNA methylation alteration in rice lines derived from introgressive hybridization of rice and Zizania latifolia Griseb. Theor Appl Genet 2006, 113:196-205.

27. Knox MR, Ellis THN: Stability and inheritance of methylation states at Pstl sites in Pisum. Mol Genet Genomics 2001, 265:497-507.

28. Baurens FC, Bonnot F, Bienvenu D, Causse S, Legavre T: Using SD-AFLP and MSAP to Assess CCGG Methylation in the Banana Genome. Plant Mol Biol Rep 2003, 21:339-348.

29. Chen $\mathrm{HG}, \mathrm{Wu}$ JS: Characterization of fertile amphidiploid between Raphanus sativus and Brassica alboglabra and the crossability with Brassica species. Genet Resour Crop Evol 2008, 55:143-150.

30. Olsson G, Ellerstrom S: Polyploidy breeding in Europe. In Brassica crops and wild allies. Edited by: Tsunoda S, Hinata K, Gomez-Campo C. Tokyo, Japan Science Society Press; 1980:167-190.

31. Karpechenko GD: Polyploid hybrids of Raphanus sativus L. $\times$ Brassica oleraceae L. Bull Appl Bot 1927, 17:305-410.

32. Karpechenko GD: Polyploid hybrids of Raphanus sativus L. $\times$ Brassica oleraceae L. Zeitschrift fur inductive Abstammungs-und Vererbungslehre 1928, 48:1-85.

33. Mukhopadhyay A, Arumugam N, Pradhan AK, Murthy HN, Yaday B, Sodhi YS, Pental D: Somatic hybrids with substitution type genomic configuration TCBB for the transfer of nuclear and organelle genes from Brassica tournefortii $\Pi$ to allotetraploid oilseed crop B. carinata BBCC. Theor Appl Genet 1994, 89:19-25.

34. Chrungu B, Verma N, Mohanty A, Pradhan A, Shivanna KR: Production and characterization of interspecific hybrids between Brassica maurorum and crop Brassicas. Theor Appl Genet 1999, 98:608-613.

35. Osborn TC, Pires JC, Birchler JA, Auger DL, Chen ZJ, Lee HS, Comai L, Madlung A, Doerge RW, Colot V, Martienssen RA: Understanding mechanisms of novel gene expression in polyploids. Trends in Genetics 2003, 19:141-147.

36. Liu B, Wendel JF: Epigenetic phenomena and the evolution of plant allopolyploids. Mol Phylogenet Evol 2003, 29:365-379.

37. Madlung A, Masuelli RW, Watson B, Reynolds SH, Davison J, Comai L: Remodeling of DNA methylation and phenotypic and transcriptional changes in synthetic Arabidopsis allotetraploids. Plant Physiol 2002, 129:733-746.

38. Xiong $L Z, X u C G$, Saghai Maroof MA, Zhang Q: Patterns of cytosine methylation in an elite rice hybrid and its parental lines, detected by a methylation-sensitive amplification polymorphism technique. Mol Gen Genet 1999, 261:439-446.

39. Kidwell KK, Osborn TC: Simple plant DNA isolation procedures. In Plant genomes: methods for genetic and physical mapping. Edited by: Beckmann J, Osborn TC. Dordrecht, Kluwer Academic Publ; 1992:1-13.

doi:10.1186/1471-2229-10-207

Cite this article as: Li et al:: Instability of chromosome number and DNA methylation variation induced by hybridization and amphidiploid formation between Raphanus sativus L. and Brassica alboglabra Bailey. BMC Plant Biology 2010 10:207.

\section{Submit your next manuscript to BioMed Central and take full advantage of:}

- Convenient online submission

- Thorough peer review

- No space constraints or color figure charges

- Immediate publication on acceptance

- Inclusion in PubMed, CAS, Scopus and Google Scholar

- Research which is freely available for redistribution 